\title{
28. PALYNOSTRATIGRAPHIC ANALYSIS OF CORES FROM SITE 493, DEEP SEA DRILLING PROJECT LEG 66 $^{1}$
}

\author{
G. R. Fournier, Gulf Research and Development Company, Houston Technical Services Center, Houston, Texas
}

\begin{abstract}
The continuous analysis of 623.5 meters of samples recovered from the three holes at Site 493 resulted in a palynostratigraphic zonation of the site. Eight distinctive zones were established and three unconformities recognized. The succession of assemblages described, from the early Miocene to the Holocene, documents vegetation changes that have taken place on the mainland in the last $20 \mathrm{~m}$.y. These vegetational shifts are in part manifestations of climatic fluctuations that occurred in the region. Correlation with the nannoplankton zonation and magnetostratigraphy is fair; magnetostratigraphic correlation is good for the early Miocene. Considerable amounts of data, including the recognition of 531 types of palynomorphs and their frequency distribution in the section, were acquired for more extensive work in the future.
\end{abstract}

\section{INTRODUCTION}

Cores from Site 493 were continuously analyzed for palynological content. The purpose of the study was to observe the nature of the palynological assemblages and to obtain information on the climatic history from the Miocene to the Holocene in adjacent Mexico. Sufficient palynomorphs were found to establish a biostratigraphic zonation of the site, which has been correlated with the nannoplankton zonation established by Stradner and Allram (this volume) for the same locality. Eight palynostratigraphic zones were established and three hiatuses recognized. Fluctuation in key species and abundance of the assemblages in the succession of palynofloras enable us to recognize several events in the climatic history of the adjacent mainland.

\section{METHOD OF ANALYSIS}

The method of analysis employed in this project has been described in detail elsewhere (Fournier, in press). The highlights of the method are the following:

1) Representative specimens of each morphotype found in the section are picked and single-mounted. A morphological code is assigned to each type for computer use. Open wet mounts are used for this initial step.

2) Counts of up to 200 palynomorphs of composite continuous samples at designated intervals are made. All wet mounts contain approximately the same amount of concentrate-one drop of the residue in glycerin suspension covered by a 22 -mm-square cover glass. All the palynomorphs observed were counted.

3) The results of the counts are input to the computer, and three printouts are obtained as follows:

a) All morphotypes in the section are arranged in stratigraphic order of appearance from younger to older and are shown vertically; their relative frequencies are displayed horizontally on a depth scale from zero to total depth and expressed in a conventional code. A complete spatial distribution of all palynomorphs and their relative frequencies are thus obtained.

b) An alphabetical list of all morphotypes for quick recognition.

c) An alphabetical presentation of each occurrence of all the morphotypes, each one sorted by sample depth, giving the frequency

\footnotetext{
${ }^{1}$ Initial Reports of the Deep Sea Drilling Project, Volume 66.
}

in the sample and the number of grains found in each case. This is a permanent record of great value for future work.

The "sensitive species" are chosen from the first appearance display. These are types whose distribution and abundance in the section are considered significant because of their uniqueness in distribution, intrinsic environmental value, or significance as key species. The distribution chart (Fig. 1, back pocket) of the sensitive species issued by the computer shows the species, represented by their codes, on the horizontal axis and the frequency distribution, expressed logarithmically, on the vertical axis against depth.

The distribution chart of significant, or sensitive, species is the basis for the zonation of the biostratigraphic section. Once the sensitive species are identified and their significance in the section recognized in terms of their presence, location, and pattern of distribution, conclusions are drawn regarding climatic changes, depositional environments, and age determinations.

\section{DATA FROM SITE 493}

Samples from the three holes drilled at Site 493 were placed in stratigraphic order and treated as if they were one single continuous stratigraphic section. Thus we obtained 115 composite samples of continuous coring, each one representing an average interval of $17.8 \mathrm{ft}$; or 5.4 meters, in the 2045 -ft. section. (It was necessary to express depth in feet because of the computer program.)

Of the 531 morphotypes recognized in the section, 59 were chosen as important or sensitive species-an average of $11 \%$ of the total types identified. This average is consistent with practically all previous work done in Tertiary sediments in other parts of the world where I have established zonations (Venezuela, Colombia, the United States, Canada, Taiwan, Japan, Turkey, etc.)

The basic data obtained from the samples in Site 493 also includes (1) single mounts of all the new species found (by new, I mean species new to our type collection, a total of 55), which were identified, photographed, catalogued, and added to our type collection. (2) Retrievable records of all the occurrences of the 531 types found, their place in the section, frequency, and number of individuals found in each sample. These records amount to a total of 1064 items, available on request of future work. 
In writing this report I made only limited use of the basic data. Detailed studies should be made on specific groups of palynomorphs, such as the fungal elements, of which I accounted for only three of the most abundant species.

\section{THE ESTABLISHMENT OF PALYNOSTRATIGRAPHIC UNITS}

The assemblage is the criterion for determining a palynostratigraphic unit. As long as an assemblage maintains its identity, it is an indication of stable conditions and no change. Vertical continuity of an assemblage is an index of how long a set of conditions lasted. In the horizontal, or geographic, sense it shows how extensive those conditions were. A significant gradual change in the characteristics of an assemblage through time indicates a shift from one biostratigraphic unit into another. But a geographic (horizontal) change in the character of the assemblage is usually an indication of biofacies shifting. An abrupt interruption of the vertical continuity of a palynological assemblage may indicate an unconformity or a fault. Reworked palynomorphs may be recognized by their erratic distribution.

\section{CHARACTERISTICS OF THE ASSEMBLAGES}

Two biological elements dominate the organic residue of all the samples from Site 493: coniferous pollen and fungal elements. Also abundant in large parts of the section are fecal pellets, not exceeding $20 \mu \mathrm{m}$ in diameter, possibly derived from extremely small, abundant crustacea. Although traces of these pellets occur throughout the section, they are extremely abundant in Zones 4 and 5 .

The coniferous pollen must have originated in upland forest not too distant from the depositional site. The bulk of the pollen was probably stream-transported rather than carried by the wind. The bulk of pine pollen-or any other pollen-falls within a few miles of its source (Traverse and Ginsburg, 1966). The fungal elements probably originated in the rain forest floor or in swampy or stagnant environments sustaining a high degree of biological degradation. Marine origin is also a possibility.

An interesting characteristic of the palynological assemblages at this site is the scarcity of dinoflagellate cysts usually abundant in marine sediments. They are virtually absent in the section except for Zone 6, which contains fairly continuous occurrence at low percentages. Reworked palynomorphs, mostly pteridophyte Cretaceous spores, occur sporadically mainly in the lower part of the section in Zones 7 and 8 .

It is reasonable to assume that the great majority of the palynomorphs found at Site 493 originated in the Mexican mainland and that they were transported to the depositional site by streams draining the mountain front and coastal areas and by wind currents.

The virtual absence of mangrove pollen in the samples indicates that no significant mangrove swamps were present in the area.

The large quantities of fungal elements found in all samples, except in Zone 5 where they are less abundant, suggest an endemic source: the rain forest floor and perhaps the seafloor as well. I intend to make a detailed study of the fungal constituents of this site in the future.

\section{COMPONENTS OF THE PALYNOFLORAS}

\section{Tree Pollen}

The pollen assemblage from trees in this site is dominated by upland species such as pine (Pinus), oak (Quercus), and Engelhardtia (Juglans). Pollen of the family Sapotaceae-trees and shrubs of tropical climates-is abundant in Zones 4 and 8. Alder pollen (Alnus) was found abundant only in Zones 1 and 2. In the tropics, alder grows in mountain areas from 2000 to 3000 meters high, as in Colombia and Venezuela (Muller, 1959). It appears for the first time in the Caribbean area in the Pleistocene (Germeraad et al. 1968). In Mexico alder is considered an upland forest component (Sears and Clisby, 1955). The pollen of Ilex (holly) occurs sporadically in Zones 3, 4, and 5. Ilex occurs in tropical and temperate regions and requires a wet climate. The pollen of Bombacaceae (Ceiba) occurs only in Zones 6 and 7. It is a tropical tree. Taxodium (cypress) pollen is found sporadically in Zones 7 and 8 . Taxodium is edaphically controlled and grows in swampy and riverine environments.

\section{Herbaceous Pollen}

Most herbaceous pollen types present in the section are from the family Compositae. The Helianthus type occurs throughout the section but is most abundant in Zones 6 and 7. The Ambrosia type is restricted to Zones 3 and 4, as is the Artemisia type pollen, which shows its acme of development in Zone 3. The pollen of Graminea-grasses and sedges-is abundant in Zones 2 and 3 and in the upper half of Zone 4.

\section{Ferns}

Fern spores, both monolete and trilete types, are important constituents of the assemblages at this site. Ferns grow best in warm to cool, very moist environments. As a group they are good indicators of wet climates (Groot and Groot 1966). They are abundant in Zones 6 and 7 and scarce in Zone 5. In Zone 4 they are more abundant. In Zone 3 they are scarce again and are abundant once more in Zone 2. Their abundance or scarcity fluctuates with the moisture available.

\section{PALYNOSTRATIGRAPHY}

\section{Description of the Biostratigraphic Units}

The continuous analysis of the stratigraphic section at Site 493 provides a clear picture of the succession of palynomorph assemblages through time in response to many factors, mainly climatic fluctuations and depositional patterns. Palynostratigraphic units are described in terms of these assemblages, each one acquiring a distinctive identity for future reference. In a limited sense these biostratigraphic units are time parameters. In welldelimited depositional basins such as the Lake Maracaibo Basin, such palynostratigraphic units exhibit a 
remarkable continuity for hundreds of kilometers and are the only reliable means of correlation.

Zone 8: 585.2-618.4 + m (1920-2029+ ft.)

Age Determination: early Miocene

The top of this unit corresponds to the base of Zone 7 and is recognized by the first occurrence of Lepidosorus sp. (52), ${ }^{2}$ probably a member of the Polypodiisporites group. The first occurrence of Helianthus type pollen (11) is at this level. The base of the continuous occurrence of Echinatisporites sp. (46) occurs just above the top of this unit. The assemblages of Zone 8 are rather poor, both in palynomorph density and number of forms. The base of the unit was not determined.

\section{Zone 7: 500-585.2 m (1640-1920 ft.)}

\section{Age Determination: early Miocene}

The base of Zone 7 is recognized by the beginning of the continuous occurrence of Helianthus above 5\% (11). Echinotisporites sp. (46) and Lepidosorus sp. (52) first occur continuously at the base of this zone. An increase in the number of species and of the density of palynomorph population is observed throughout Zone 7 , indicating an increase in humidity and stream activity. The top of the zone corresponds to the base of Zone 6 . Two tricolpate types (57 and 59) occur only within Zone 7.

\section{Zone 6: $362-500 \mathrm{~m}$ (1188-1640 ft.)}

\section{Age Determination: early Miocene}

A pronounced hiatus, based on nannoplankton analysis, separates this zone from the overlying one. The top of the unit is distinguished by the top of the continuous occurrence of the following forms: Polypodiisporites undulatus (12), a fern spore; Pachydermites diederexi (41); Echinatisporites sp. (46); and dinoflagellate cysts (45) that occur significantly only in this unit. Other forms characteristic of this zone are the pollen of Bombax (47), found only in Zones 6 and 7; Polypodiisporites favus (48), a fern spore found significantly from Zone 6 down; a form of Polypodiisporites (51) found only in Zone 6; and another fern spore (52), possibly a member of the genus Lepidosorus, present only in Zones 6 and 7. Jussitriporites cf. J. undulatus Gonzalez, 1967 (53) appears in Zone 7 at low percentages and seems to be unique to this interval. Undulatisporites undulapolus (56) occurs in the lower part of the zone continuously at 1 and $2 \%$ frequency. It may not be significant. Dinoflagellate cysts, mostly hystrichospheres (45), occur continuously only in Zone 6. A form of Proxapertites (50) occurs continuously only in this unit, at low percentages.

\footnotetext{
2 The 59 morphotypes illustrated in Plates 1 through 4 correspond to the numbers in Figures 1 to 59 . In this section, the numbers in parentheses refer to the figures in the plates.
}

Zone 5: 243.5-362.0 m (799-1188 ft)

\section{Age Determination: late Miocene}

The top of this zone is determined by the last occurrence of Pachydermites diederexi Germeraad et al. (1968) (41). The top of this unit is also the top of the Miocene. A tricolporate pollen grain (40) last appears continuously at the top of this zone. In general, there is a decrease in frequency of most of the species in this interval compared with the unit below. The base of the unit rests on a rather pronounced unconformity recognized by nannoplankton analysis with all middle Miocene sediments missing.

\section{Zone 4: 148.5-243.5 m (487-799 ft.)}

\section{Age Determination: early Pliocene}

The top of this unit corresponds to the base of Zone 3 , where the presence of a hiatus is suggested by a change in lithology and in the character of the floras. The top of Zone 4 is recognized by the last occurrence of what is probably a type of oak (31 and 32). The two forms are probably both morphotypes of the same species, one a prolate presentation, the other a polar presentation. Although they were separated during counting, their identical distribution shows that they probably are the same species (found only in Zones 4 and 5). Several fern spores exhibit their last occurrences within this zone, including one species of Polyciisporites (33) and three species of Polypodiisporites (34, 35, 37). Multiaerolites formosus Van der Hammen (39) occurs only in Zones 4 and 5.

\section{Zone 3: 88.0-148.5 m (290-487 ft.)}

\section{Age Determination: late Pliocene}

Lithological change and a significant change in the assemblages indicates that the top of this unit may also be a hiatus. It is also the top of the Pliocene. It is characterized by a much lower density in the palynomorph content and by the highest incidence of pollen of Compositae. One type, Artemisia (23), exhibits its highest relative and more continuous occurrence in this interval than in the remaining of the section. The $\mathrm{Am}$ brosia type (22) is limited in appearance to Zones 3 and 4. The Helianthus type (11) is common throughout the section and abundant in Zones 6, 7, and 8 . The base of the unit rests on a hiatus marked by the top of the continuous occurrence of several representatives of the family Sapotaceae (7), a tropical and subtropical group of plants. Sporadic occurrences of Sapotacea pollen above the base of Zone 3 may be reworked.

\section{Zone 2: $21.5-88.0 \mathrm{~m}$ (85-290 ft.)}

\section{Age Determination: Quaternary}

The top of this zone is determined by the last occurrence of the following types: Concentricystis (13), the spore Foraminisporis cf. F. foraminis (14), graminea 
and sedge types (15), Triplanosporites sp. (16), Trilites sp. (17), and Hedyosmum sp. (18). The pollen of Alnus occurs suddenly and strongly from the base of Zone 2 to the top of the section.

\section{Zone 1: 0-21.5 m (0-85 ft.)}

\section{Age Determination: Holocene}

The palynological assemblage in this interval is dominated by pollen of conifers, mainly pine, and by fungal elements. Both components constitute about $80 \%$ of the assemblage. Oak pollen and the spores of a few fern types make up the remaining $20 \%$ of the flora. The sparsity of species may indicate dry climate and diminishing stream activity. The top of the unit is the seafloor. The base corresponds to the top of Zone 2 .

\section{PALEOCLIMATES}

The detailed analysis of the palynofloras at Site 493 provides an opportunity to observe the changes in vegetation that took place on the Mexican mainland. The palynofloral spectrum of a depositional site reflects the vegetational shifts at the source and is influenced by such factors as distance from shore, depth of water, tectonic setting, drainage patterns, and marine currents.

Conditions of deposition and source areas at this site seem to have been fairly stable from the Miocene to the Quaternary. I believe the main changes in the character of the assemblages and in the density of palynomorph population are due mainly to climatic fluctuations. I also believe that the density of land-derived palynomorphs at this site is mainly related to transport by streams and that it is directly proportional to it. Changes in the number of species may be mainly related to fluctuations of the mean temperature. As a rule, there is a higher number of species in warm climates than in cold ones.

Of the 59 sensitive species depicted in Figure 1, 20 are pteridophyte spores, most of them filicales. Ferns prefer warm to cool climates with abundant rainfall-the climate of mountain slopes in the tropics. The relative abundance of fern spores and their fluctuations are fairly good indicators of changing climatic conditions. Groot and Groot (1966), in their study of deep sea cores off the coast of Chile, consider fern spores to be indicators of humid climate.

The fluctuations of the frequency curves of the 20 fern spores summarized in one curve in Figure 1 generally indicate the sections in the sedimentary column where changes from wet to dry climate, and vice versa, have occurred. A more detailed account is given in Figure 2, where all the 140 fern spore types in the analysis have been tabulated according to their relative frequency in the section at 100 -ft. intervals.

\section{Paleoenvironments at Site $\mathbf{4 9 3}$}

The main events in the climatic history in the general area of Site 493 encompass a period of about 20 m.y. The eight zones depicted in Figure 1 and described on the basis of their palynological assemblages represent relatively stable periods in the climatic history of the region.

The basal sediments rest unconformably on basement rocks and are of early Miocene age. The cimate during Zone 8 time was relatively dry and warm, as indicated by the limited number of species and by the presence of Sapotacea pollen (15\%) and scarce Ilex. During Zone 7 time the amount of rainfall increased, as indicated by the appearance of several fern species. The average temperature was probably higher. Typical tropical climate prevailed in the area until the end of Zone 6 time. It is interesting to note that oak pollen is missing in Zones 8 and 7 and begins to appear sporadically in late Zone 6 time.

The sedimentary record is missing during the entire middle Miocene. Sediments of late Miocene age rest on a hiatus at 362 meters depth, the base of Zone 5 .

Most of the fern spores from Zone 6 are absent in Zone 5, except for a few hardy species. The sudden abundant occurrence of several species of oak in Zone 5 , together with abundant pine, indicates warm climate (Sears and Clisby, 1955). The climate during Zone 5 time was rather dry and warm according to the indicators. The lowest concentration of fungal elements is in Zone 5, possibly another indication of drier conditions during this time.

During Zone 4 time the mean temperature remained the same, but an increase in the pollen concentration and in the number of species indicates an increase in precipitation and stream activity. A hiatus, evidenced by a change in lithology, indicates that these conditions were interrupted at the end of Zone 4 time.

During Zone 3 time the climate became colder and drier, as indicated by the virtual disappearance of the tropical Sapotaceae and of some species of oak and by the scarcity of ferns. The end of the Pliocene is marked by a hiatus. A notable change in the character of the floras and a significant increase of seven fern spores above this unconformity, indicate an increase in stream activity with high precipitation. This interpretation is reinforced by the occurrence of high counts of oak and alder pollen in Zone 2, a definitie indicator of moist climate (Sears and Clisby, 1955). The climate during Zone 2 time was cooler and moist, as indicated by the significant decrease in frequency of Helianthus (sunflower group), which prefers dry soils. This pollen group diminishes significantly in frequency in Zone 2, another fact pointing toward an increase in precipitation during Zone 2 time, or early Quaternary.

A probable hiatus separates Zone 2 from Zone 1 at 21.5 meters depth. The sudden disappearance of seven species typical of Zone 2 may be indication of an unconformity. Not enough information is available from samples in Zone 1. The limited number of species recorded in this interval as compared to Zone 2 may indicate drier conditions and less stream activity. The temperature may not have changed appreciably from Zone 2 to Zone 1 times. 


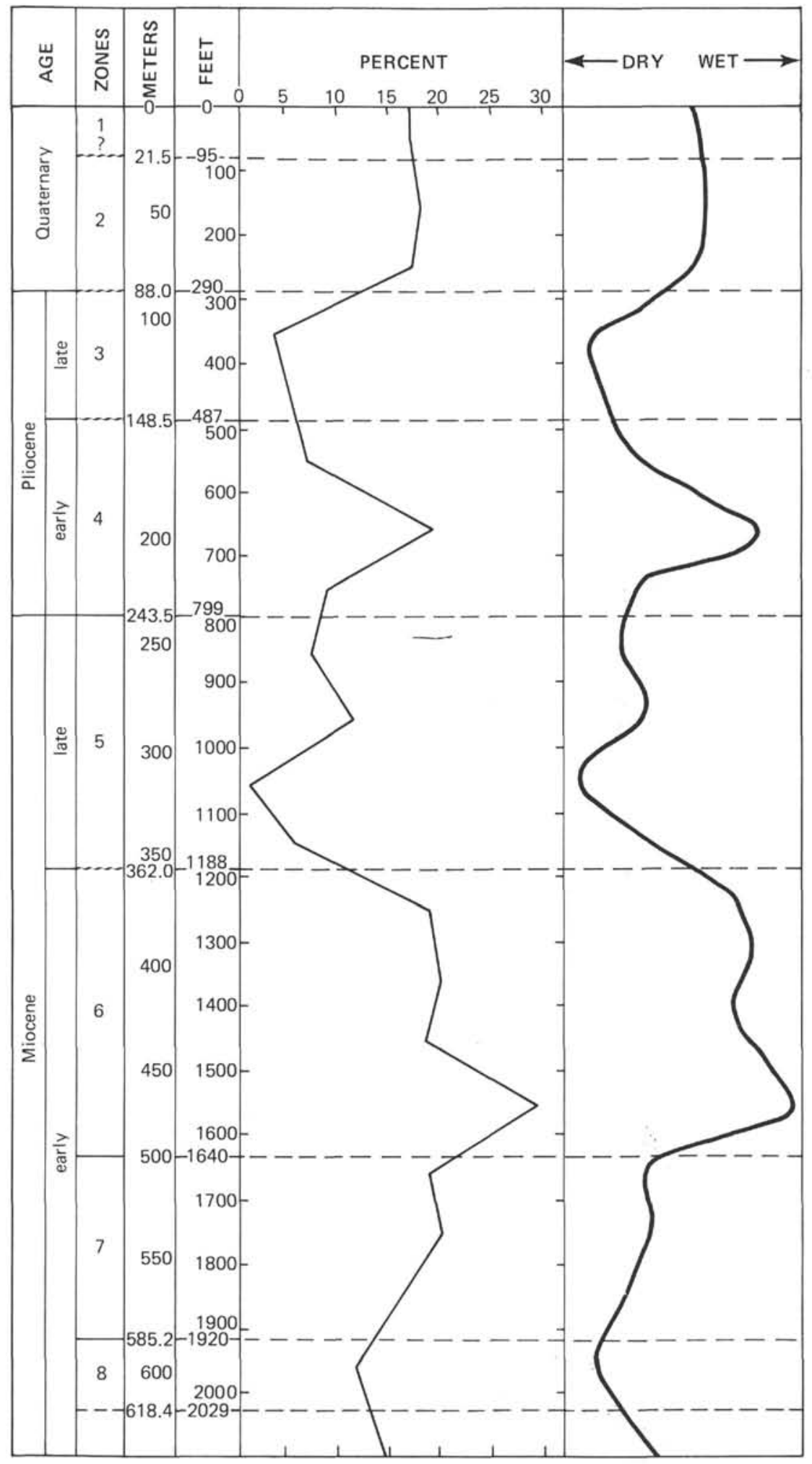

Figure 2. Distribution of fern spores at Site 493.

\section{Correlation with the Nannoplankton Zonation}

Fair correlation exists between my palynostratigraphic zonation at Site 493 and the nannoplankton zones established by Stradner and Allram (this volume).
Several palynological tops occur below the nannoplankton tops, indicating that they are somewhat younger. For example, the top of Zone 2 is about 8.5 meters below the top of NN20, the top of Zone 3 is about 30 meters below the top of NN18, the top of Zone 
5 is close to 18.5 meters below the top of NN11, and the top of Zone 8 is about 19 meters below the top of NN3. This observation is consistent with findings elsewhere that established correlations between zonations based on marine organisms and those based on detrital elements transported from the land to the marine environment.

The relationship between the palynological and the nannoplankton zones is as follows:

\begin{tabular}{cl}
$\begin{array}{c}\text { Palynological } \\
\text { Zone }\end{array}$ & \multicolumn{1}{c}{ Nannoplankton Zone } \\
\hline 1 & $\begin{array}{l}\text { Upper part of NN20 and NN21 } \\
\text { Lower part of NN20, whatever remains of } \\
\text { NN16-NN18, and probably the upper part } \\
\text { of NN15 }\end{array}$ \\
& $\begin{array}{l}\text { Part of NN15 } \\
\text { Lower part of NN15 and uppermost part of }\end{array}$ \\
3 & $\begin{array}{l}\text { NN11 } \\
\text { Part of NN11. The base of Zone 5 rests on a } \\
\text { rather pronounced unconformity in which }\end{array}$ \\
5 & $\begin{array}{l}\text { NN6-NN10, inclusive are missing } \\
\text { Lowermost part of NN5 and the upper two- } \\
\text { thirds of NN4 }\end{array}$ \\
6 & $\begin{array}{l}\text { Lower third of NN4 and NN3 } \\
\text { Lower part of NN3 and upper part of NN2 }\end{array}$ \\
7 & .
\end{tabular}

a Correlation is unclear because of dissolution and/or missing index species.

\section{Correlation with Magnetostratigraphy}

In Figure 1 the magnetostratigraphy determined by Mitsuma has been placed at the extreme right. Lines of correlation with the palynology zones have been drawn and the following observations are made:

\begin{tabular}{cl}
$\begin{array}{c}\text { Palynological } \\
\text { Zone }\end{array}$ & \multicolumn{1}{c}{ Magnetostratigraphy } \\
\hline 1 & Epoch 1 (Brunhes) \\
2 & Epochs 2 and 3 (upper Matuyama) \\
3,4 & Epochs 4 (lower Matuyama) and 5 \\
5 & Epoch 6, 7, and 8 \\
6 & Epoch 16 \\
7 & Epoch 17 \\
8 & Not correlated \\
\hline
\end{tabular}

Note: Correlation is inconclusive for Zones 1 through 4.

\section{DISCUSSION}

The fact that dinoflagellate cysts occur in significant numbers in only one part of the section, Zone 6 , is noteworthy and may indicate a period of falling sea level and shallowing in the depositional areas. Total emergence at the site took place at the end of Zone 6 time. The resulting hiatus represents either nondeposition or removal of all middle Miocene sediments. Dinoflagellate cysts occur again in the uppermost part of Zone 4 just below the unconformity at the top of the zone. This could be a repetition, on a smaller scale, of the preceding events.

The dinoflagellate cysts with a specific gravity closer to that of water than to that of detrital palynomorphys may require a certain water depth and nonturbulence to sink to the bottom. This may explain their absence in an area where oceanic, open sea conditions and relatively deep water have prevailed since the Miscene, except for brief periods of time.

Changes in climate and tectonic events (including volcanism) affect the land floras immediately, and the results are reflected at once, geologically speaking, in the marine depositional sites. It takes longer for marine forms to be affected. This may explain why the tops of palynostratigraphic units occur earlier in the sedimentary column than the tops of nannoplankton units.

\section{ACKNOWLEDGMENTS}

I am grateful to Dr. Nahum Schneidermann and to Dr. Bernard Shaffer for their valuable suggestions in the preparation of the manuscript. I am also indebted to the Gulf Research and Development Company for giving me the opportunity and the time to do this work.

\section{REFERENCES}

Fournier, G. R., in press. Method of analysis for Tertiary basins using the computer. Proceedings Fourth International Palynological Conference, Lucknow 1978-79.

Germeraad, J. H., Hopping, C. A., and Müller, J., 1968. Palynology of Tertiary sediments from tropical areas. Rev. Paleobotan. Palynol., 6(No. 3/4):189-348.

Gonzalez Guzman, A. E., 1967. A Palynological Study on the Upper Los Cuervos and Mirador Formations: Leyden (E. J. Brill).

Groot, J. J., and Groot, C. R., 1966. Pollen spectra from deep-sea sediments as indicators of climatic changes in southern South America. Mar. Geol., 4 (No. 6):525-537.

Muller, J., 1959. Palynology of Recent Orinoco delta and shelf sediments-reports of the Orinoco Shelf Expedition. Micropaleontology, 5:1-32.

Sears, P. B., and Clisby, K. H., 1955. Palynology of Southern North America-Part 4: Pleistocene climate in Mexico. Geol. Soc. Am. Bull., 66:521-530.

Traverse, A., and Ginsburg, R. N., 1966. Palynology of the surface sediments of Great Bahama Bank as related to water movement and sedimentation. Mar. Geol., 4(No. 6):417-459.

\section{SELECTED BIBLIOGRAPHY ${ }^{3}$}

Cross, A. T., Thomson, G. G., and Zaitzeff, J. B., 1966. Source and distribution of palynomorphs in bottom sediments, southern part of Gulf of California. Mar. Geol., 4 (No. 6):465-524.

Habib, D., 1970. Holocene Palynology of the Middle America Trench near Tehuantepec, Mexico. Geol. Soc. Am. Bull., Mem. 126: 234-261.

Jansonious, J., and Hills, L. V., 1976. Genera file of fossil spores. University of Calgary, Dept. of Geology.

Kahn, A. M., and Martin, A. R. H., 1971. A note on Genus Polipodiisporites, R. Potonie. Pollen Spores, 13(No. 3):475-480.

Krutzsch, W., 1959. Mikropaleontologische (sporenpalaontologische) Untersuchungen in der Braunkohle des Geiseltales. Geologie, 2122: Berlin (Akademie-Verlag), 1-425. 1962-63. Atlas der mittel-und jungtertarien dispersen Sporen und Pollensowie der Microplanktonformen des nordlichen Mittel-europas, 1, 2, 3: Berlin (Veb Deuscher Verlag der Wissenschaften).

Lozano-Garcia, S., 1979. Atlas de polen San Luis Potosi, Mexico. Pollen Spores, 21(No. 3):287-336.

Traverse, A., Spackman, W., Ames, H. T., et al., 1979. Catalog of fossil spores and pollen: Late Cretaceous and early Tertiary spores and pollen from the USA and the USSR (Vol. 41): University Park (Pennsylvania State University Press).

\footnotetext{
${ }^{3}$ The following sources were used in scientific identification of some of the species.
} 


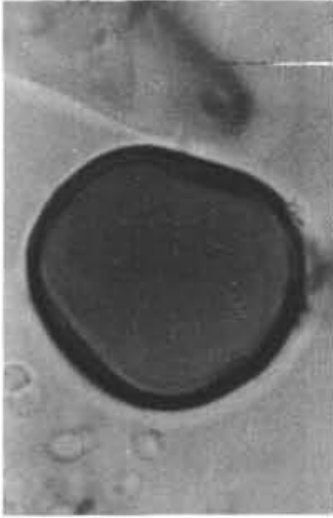

1

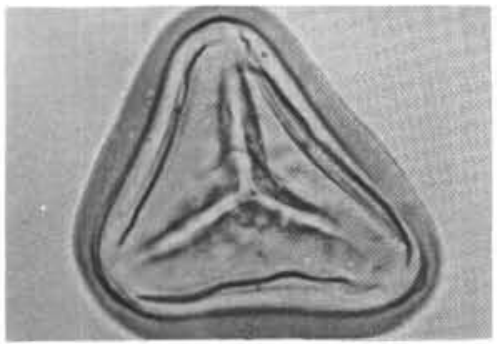

5

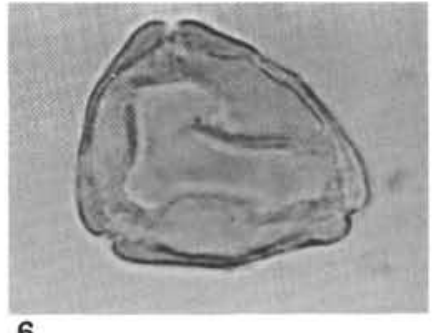

6
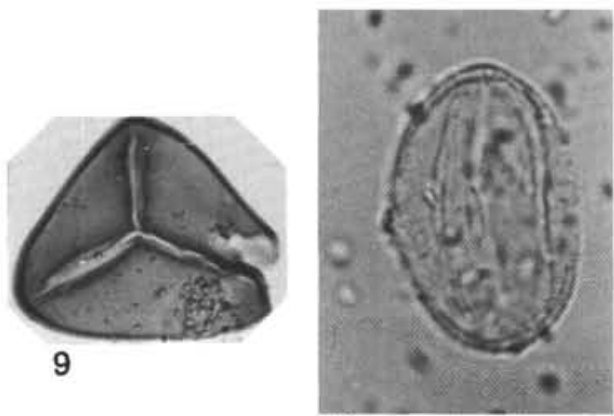

10

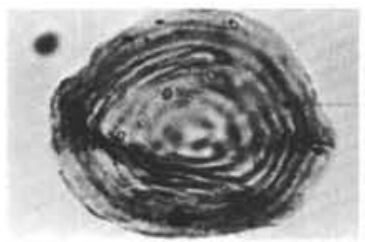

13

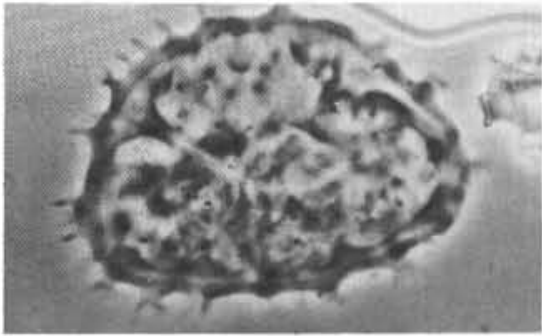

14

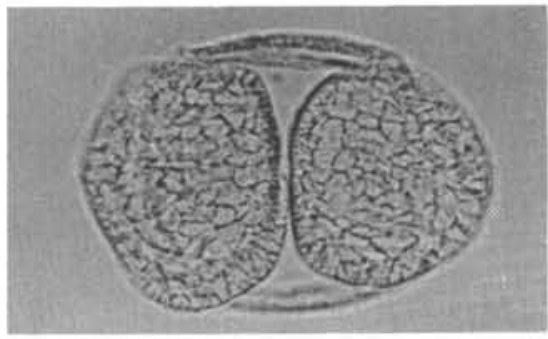

3

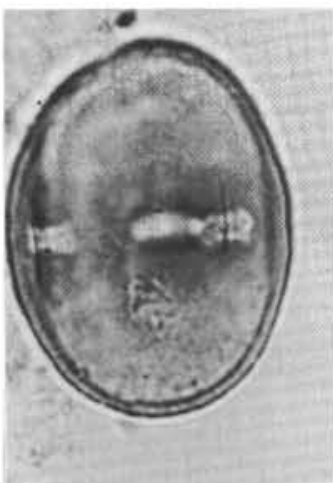

7

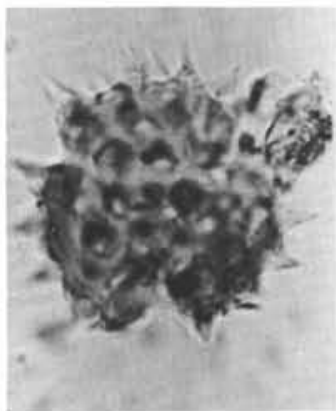

11
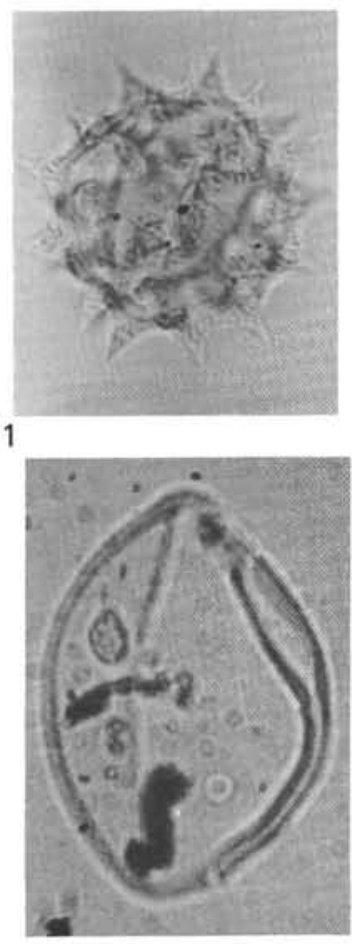

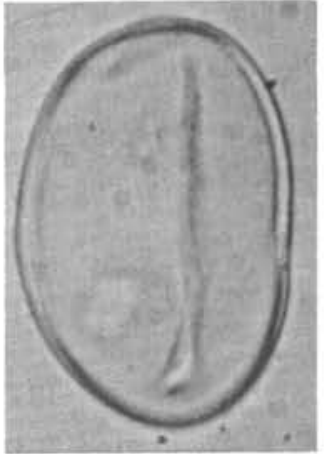

4

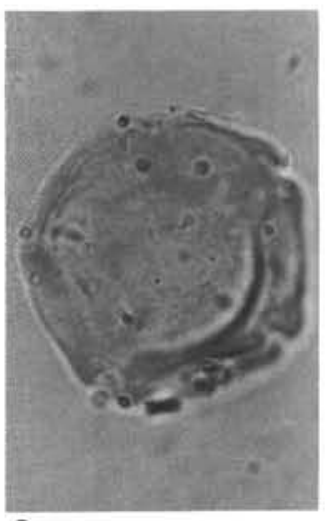

8
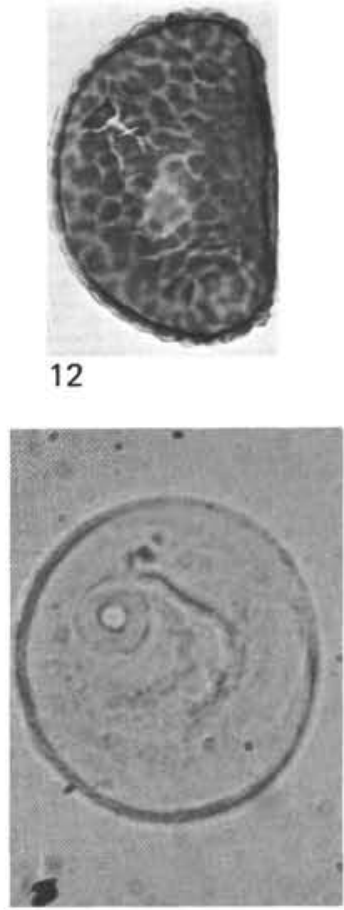

15

Plate 1. Sensitive species (Figs. 1-15). 1. Fungal spore, $16 \mu \mathrm{m}$. 2. Fungal spore, $63 \mu \mathrm{m}$. 3. Pine pollen, $82 \mu \mathrm{m}$. 4. Polypodiisporites sp., $32 \mu \mathrm{m}$. 5. Stereisporites? sp., $40 \mu \mathrm{m}$. 6. Engelhardtia (Juglans), $23 \mu \mathrm{m}$. 7. Sapotacea sp., $45 \mu \mathrm{m}$. 8. Alnus sp. (alder), $18 \mu \mathrm{m}$. 9. Thyrsopteris cf. T. elegans, $40 \mu \mathrm{m}$. 10. Quercus (oak), $20 \mu \mathrm{m}$. 11. Compositae, Helianthus type, $20 \mu \mathrm{m}$. 12. Polypodiisporites undulatus, $40 \mu \mathrm{m}$. 13. Concentricystis, $35 \mu \mathrm{m}$. 14. Foraminisporis cf. F. foraminis, $43 \mu \mathrm{m}$. 15. Graminea, 45 (1.) and 30 (r.) $\mu \mathrm{m}$. 


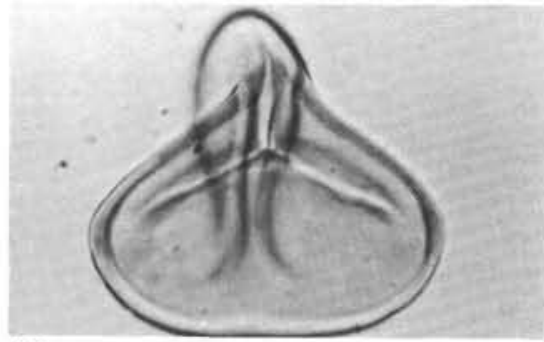

16

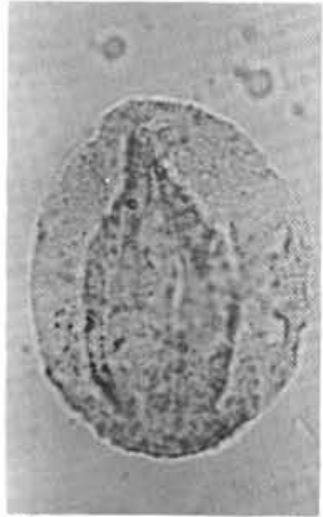

20

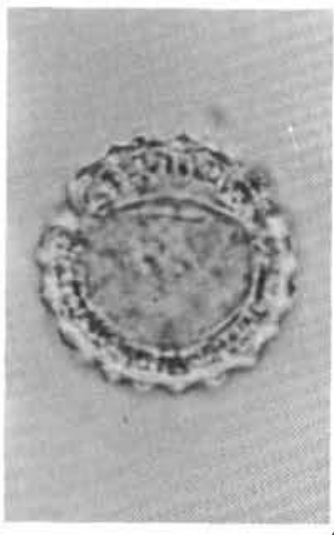

23
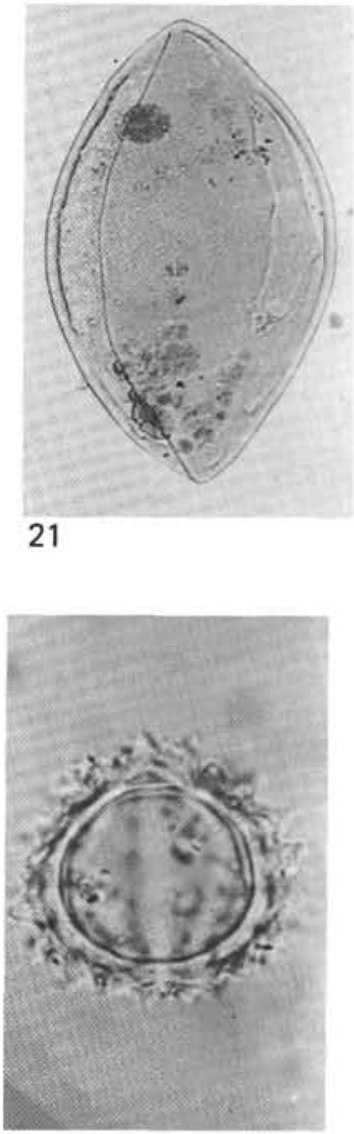

21

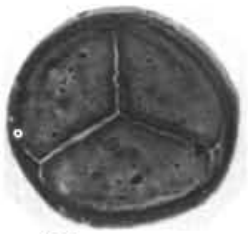

17

22

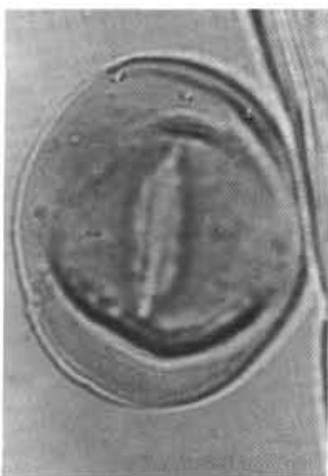

18
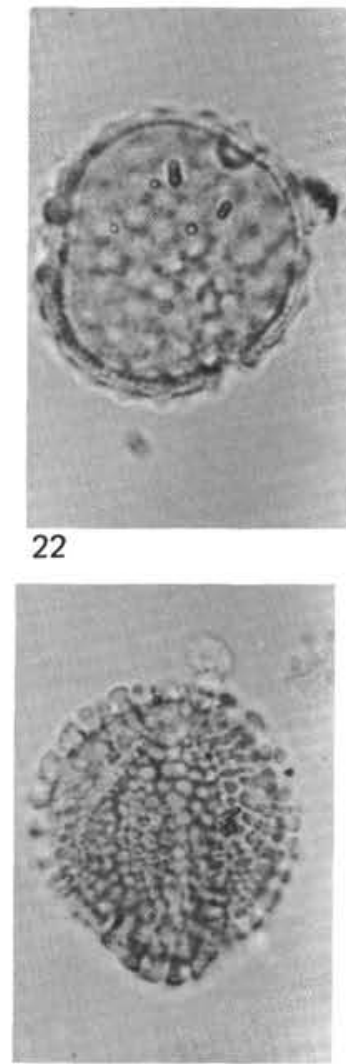

24

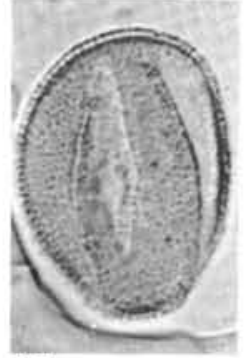

27

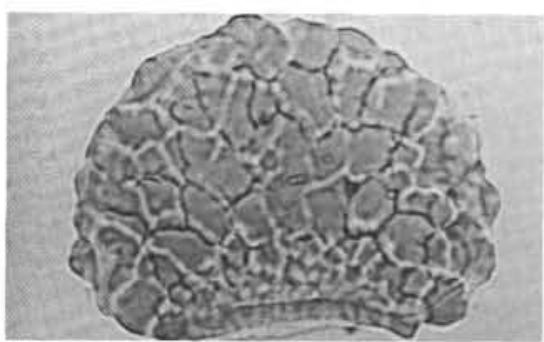

28

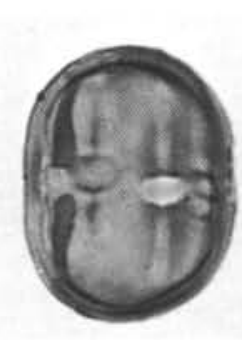

29

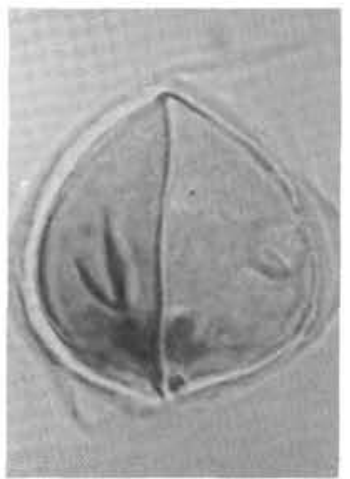

19

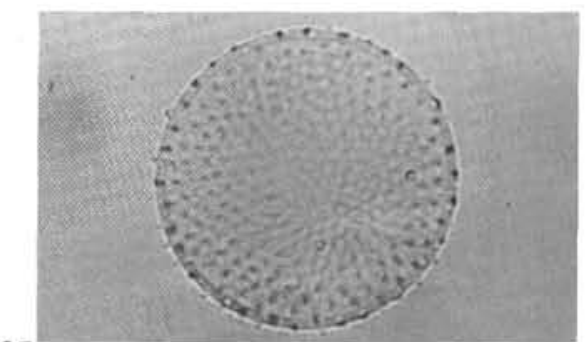

25
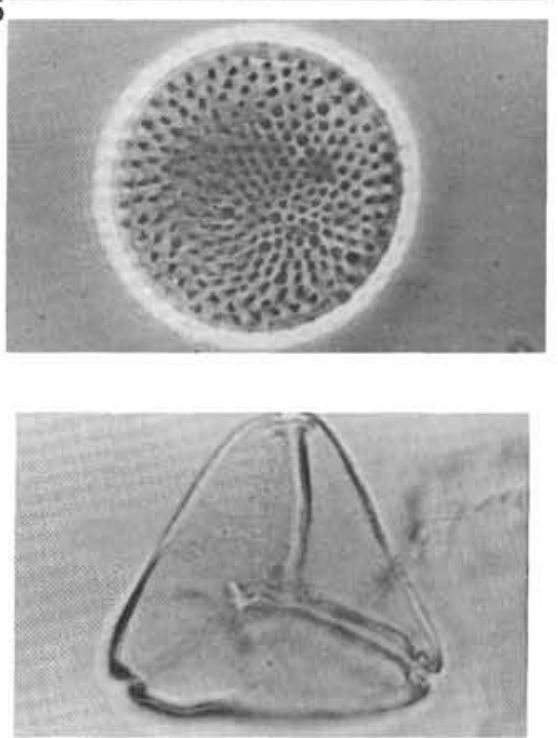

26

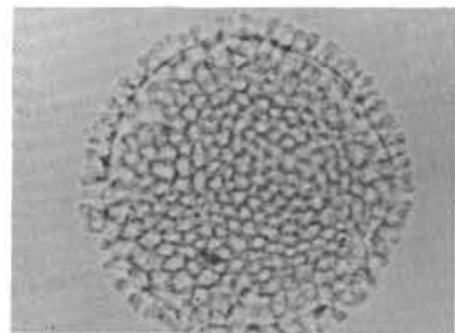

30

Plate 2. Sensitive species (Figs, 16-30). 16. Triplanosporites sp. $41 \mu \mathrm{m} .17$. Trilites sp., $37 \mu \mathrm{m} .18$. Hedyosmum sp., $35 \mu \mathrm{m} .19$. Triplanosporites sinuosus, $35 \mu \mathrm{m}$. 20. Perfotricolpites cf. P. digitatus, $30 \mu \mathrm{m}$. 21. Monosulcites, $280 \mu \mathrm{m}$. 22. Compositae, Ambrosia type, $21 \mu \mathrm{m}$. 23. Compositae, Artemisia type, $24 \mu \mathrm{m}$. 24. Ilex sp., $30 \mu \mathrm{m}$. 25. Inaperturate pollen, $35 \mu \mathrm{m}$. 26. Syncolporites sp., 30 $\mu \mathrm{m} .27$. Retitricolpites sp., $30 \mu \mathrm{m}$. 28. Polypodiisporites vulgare, $50 \mu \mathrm{m}$. 29. Manilkara lesquereuxiana, $40 \mu \mathrm{m}$. 30. Convolvulacia sp.?, $60 \mu \mathrm{m}$. 


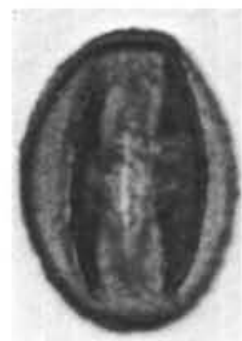

31

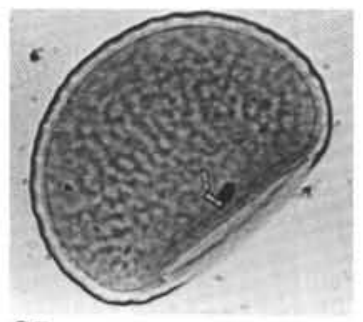

35

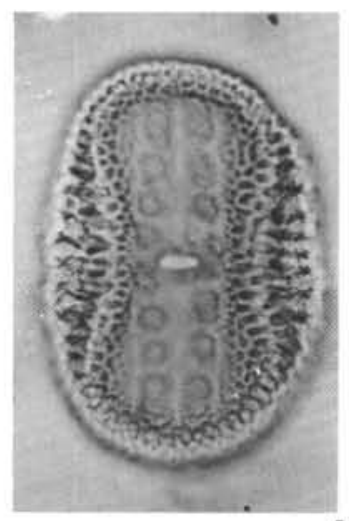

39

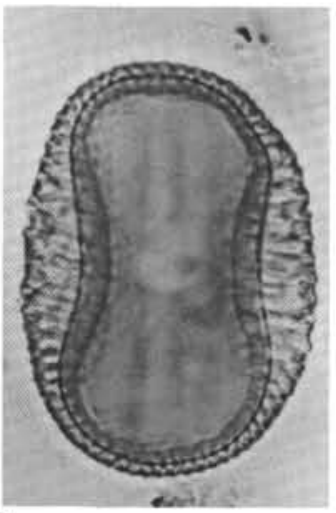

9

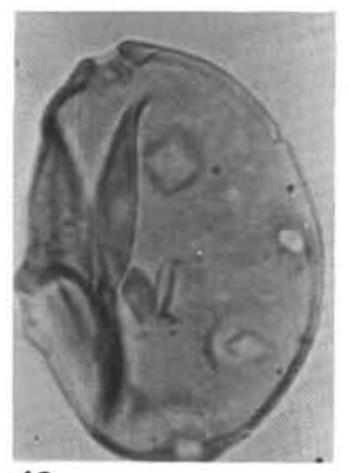

42

32

36
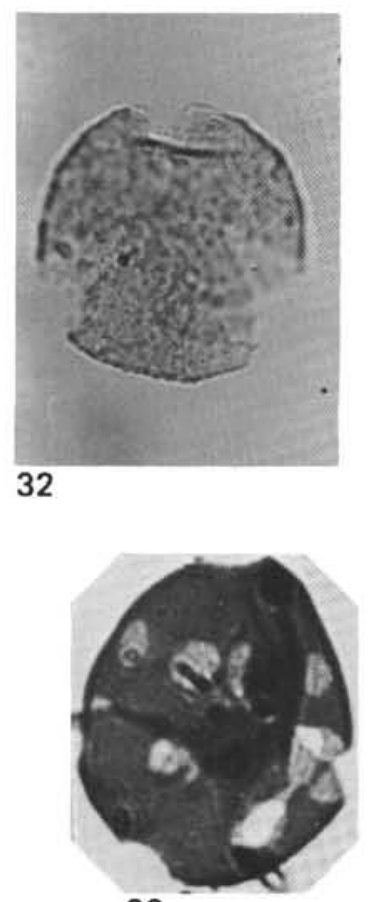

37

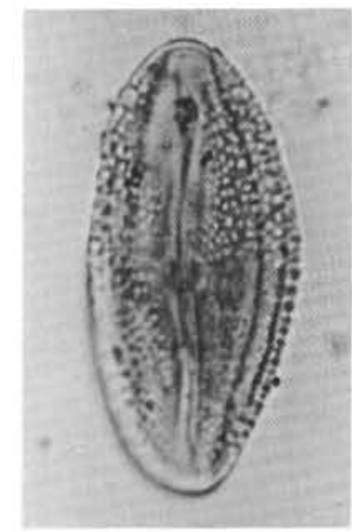

40

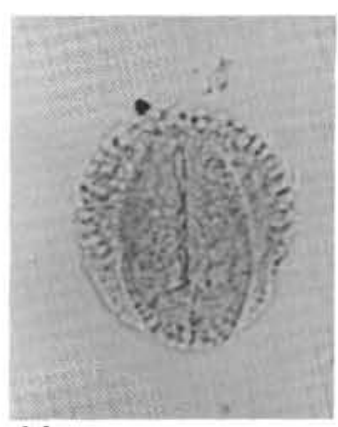

44

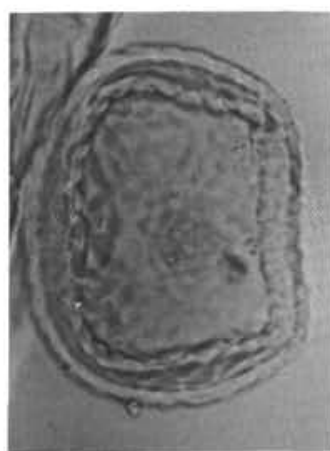

34

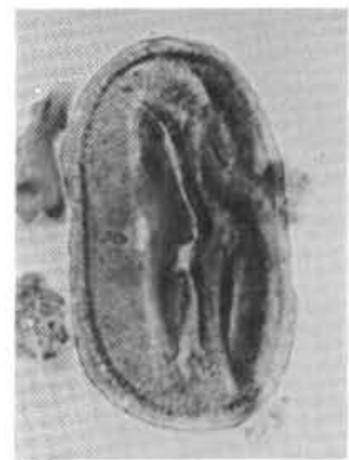

38

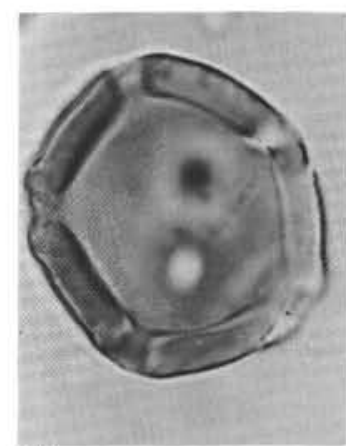

41

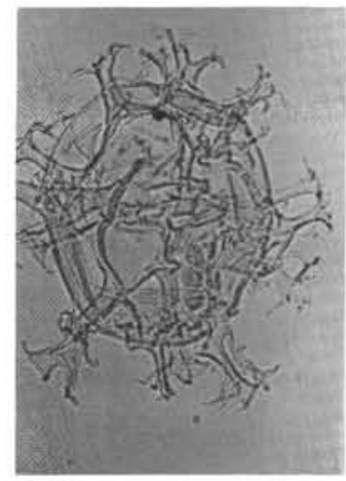

45

Plate 3. Sensitive species (Figs. 31-45). 31. Quercus sp. (oak), $33 \mu \mathrm{m}$. 32. Quercus sp. (oak), $30 \mu \mathrm{m}$. 33. Polypodiaceisporites sp., $40 \mu \mathrm{m} .34$. Polypodiisporites $\mathrm{sp}$., $55 \mu \mathrm{m}$. 35. Polypodiisporites sp., $74 \mu \mathrm{m}$. 36. Periporites sp., $32 \mu \mathrm{m}$. 37. Polypodiisporites sp., $40 \mu \mathrm{m}$. 38 . Retitricolporites sp., $48 \mu \mathrm{m}$. 39. Multiaerolites formosus, $39 \mu \mathrm{m}$. 40. Retitricolporites sp., $45 \mu \mathrm{m}$. 41. Pachydermites diederixi, $28 \mu \mathrm{m} .42$. Periporites sp., $40 \mu \mathrm{m}$. 43. Polypodiaceisporites abuncus, $40 \mu \mathrm{m}$. 44. Retitricolporites sp., $22 \mu \mathrm{m}$. 45. Dinoflagellate cysts, $50 \mu \mathrm{m}$. 


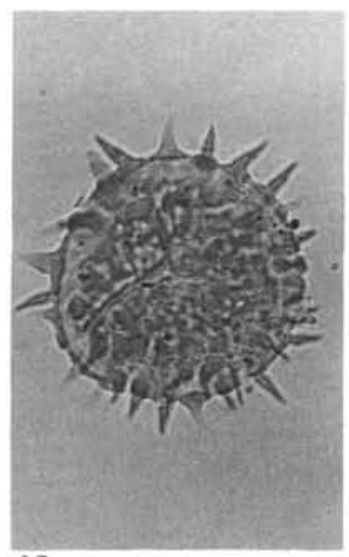

46

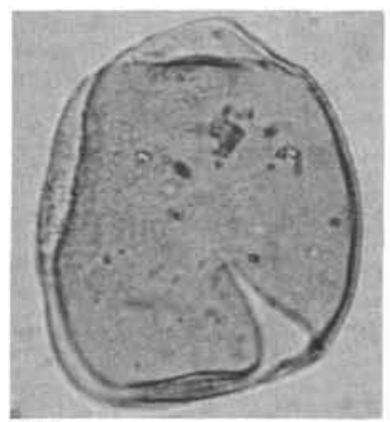

50

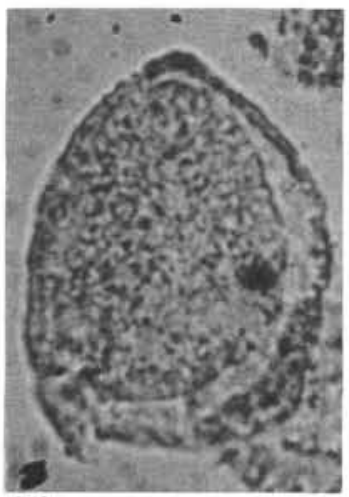

54

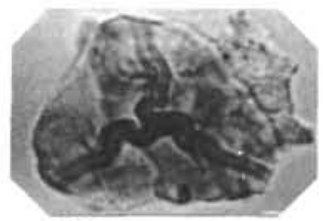

56

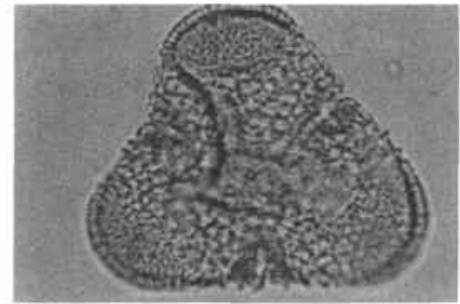

47

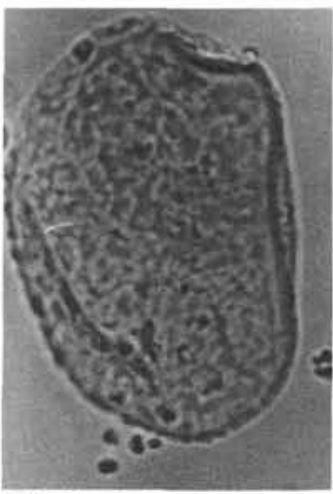

51

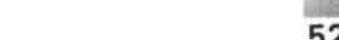

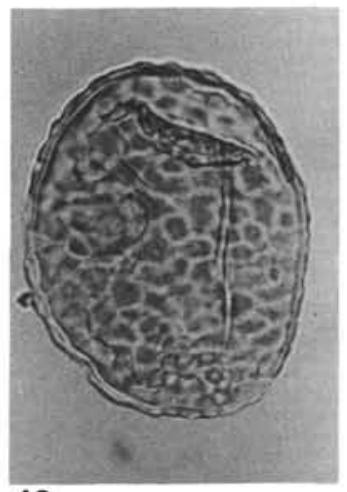

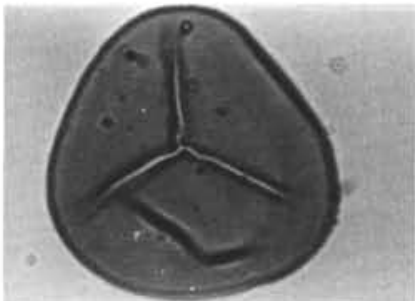

49
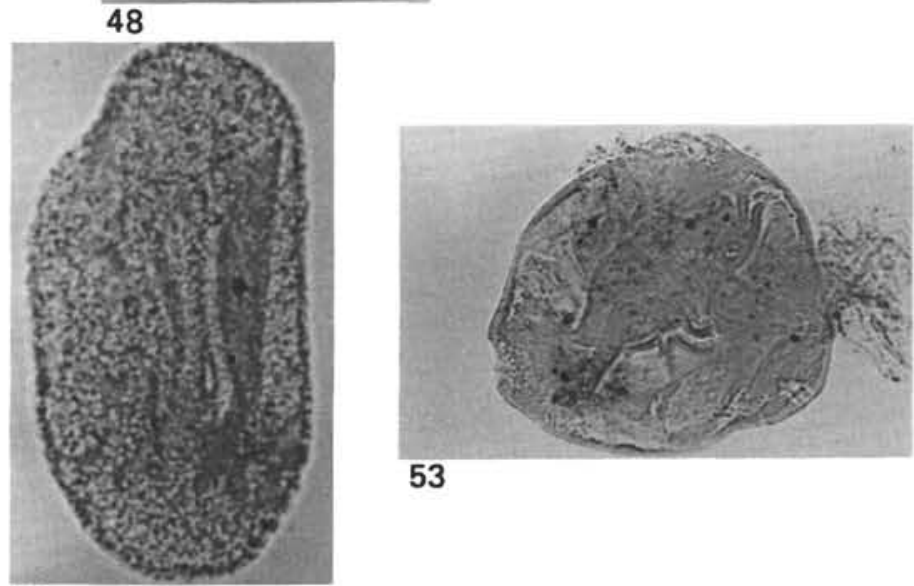

53

52
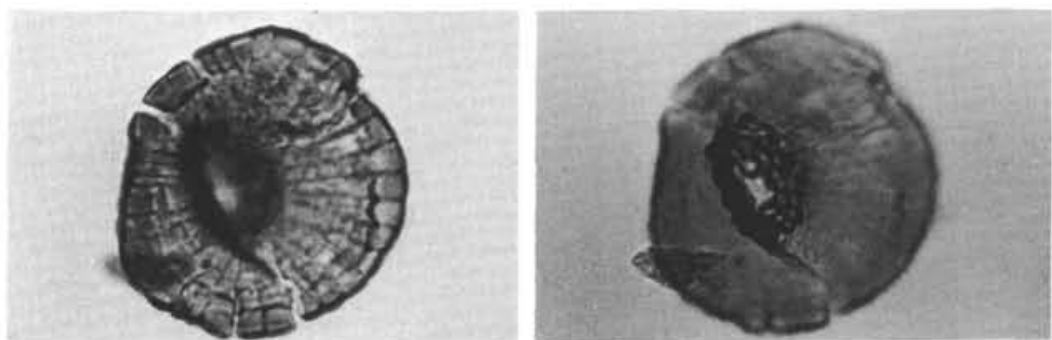

55

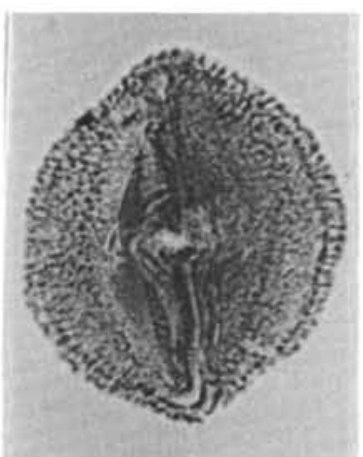

57

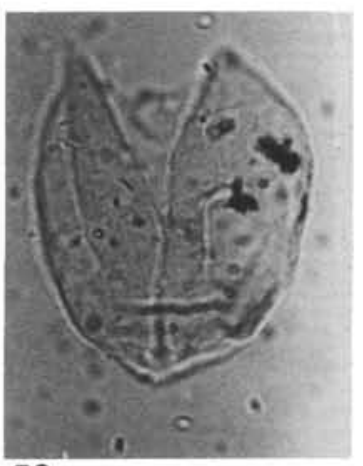

58

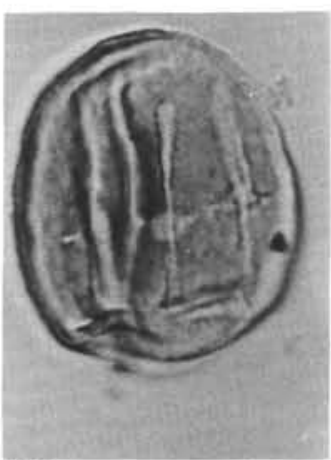

59

Plate 4. Sensitive species (Figs. 46-59). 46. Echinatisporis cf. E. bockwitzensis, $40 \mu \mathrm{m}$. 47. Bombacaceae, (Ceiba), $52 \mu \mathrm{m} .48$. Polypodiisporites favus, $62 \mu \mathrm{m}$. 49. Alsophilidites sp., $30 \mu \mathrm{m}$. 50. Proxapertites sp., $70 \mu \mathrm{m}$. 51. Polypodiisporites sp., $44 \mu \mathrm{m}$. 52 . Microfoveolatosporis pseudodentatus, $65 \mu \mathrm{m}$. 53. Jussitriporites cf. J. undulatus, $85 \mu \mathrm{m}$. 54. Longapertites sp., $50 \mu \mathrm{m}$. 55 . Callimothallus pertusus, $45 \mu \mathrm{m}$. 56. Undulatisporites $\mathrm{sp}$. (reworked), $21 \mu \mathrm{m}$. 57. Tricolporopollenites sp., $40 \mu \mathrm{m}$. 58. Taxodium sp., $29 \mu \mathrm{m}$. 59 . Psilatricolporites sp., 27 $\mu \mathrm{m}$. 